\title{
NOTE ON THE OPTIMAL SIZE OF GOVERNMENT
}

\author{
TING CHAO CHIUNG \\ Michigan State University, USA
}

\begin{abstract}
Since government is a nonprofit organization, I apply firm theory under zero profit condition to analyze the optimal size of government. Government should minimize short-run average cost while demand for public service is equal to supply of public service. The optimal size of government implies (1) tax is minimized under balance budget given public service and (2) budget surplus and budget deficit are inefficient (i.e., balance budget is Pareto optimum).
\end{abstract}

\section{JEL CLASSIFICATION \& KEYWORDS}

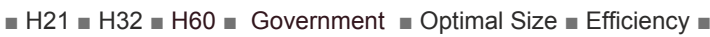
Minimum Tax n Budget Balance

\section{INTRODUCTION}

Samuelson [1954] used marginal rate of substitution (i.e., demand for public service) and marginal rate of transformation (i.e., supply of public service) to determine the optimal public expenditure. In other words, the optimal size of government is Pareto equilibrium. Even Samuelson himself recognized that his subtle achievement does not provide any practical policy for us to improve government efficiency as well as determine the optimal size of government under the technology we have today.

Barro [1989] defined the optimal size of government to be the size that maximizes economic growth. Econometric growth model is the theoretical framework to study the optimal size of government instead of supply and demand. Chobanov and Mladenova [2009, p. 9] reported that the appropriate ratio of government expenditure to GDP ranges from $17 \%$ to $40 \%$. This range seems too wide to make any sense for those who want to build government on appropriate size.

Besides Samuelson's approach and Barro's approach, can we work out an alternative theory to investigate efficiency of government (i.e., the optimal size of government) like Pareto optimum? Efficiency involves three concepts. First, supply of output matches demand for output. If supply is not equal to demand, resources are misallocated. When public sector oversupplies (e.g., transfer payment, medication and social security), government crowed out resources that private sector can use for investment (e.g., Carlstrom and Gokhale [1991] and Landau [1983]). Moreover, Karras [1997] found that there is negative relationship between productivity of government and government size. Economic growth declines when public sector oversupplies.

Hsieh and Lai [1994] pointed out that the relation between government size and economic growth vary from 1885 to 1987 in G-7 countries. If government undersupplies (e.g., transportation, law enforcement and education), some resources are misallocated to private sector. In this case, economic growth accelerates when public sector expands. Ram [1987] demonstrated that government size creates positive effect on economic growth on lower income countries, which are usually short of public service. Heitger [2001] divided government expenditure into consumption spending and investment spending. The former impedes economic growth; the latter enhances economic growth.
To summarize, we have to introduce supply and demand into analysis of the optimal size of government.

In addition to supply and demand, we need to ask another important question. Do economic agents produce output efficiently in the sense of substance? The second concept is: volume of input is minimized, given volume of output and technology. It means cost function itself is minimized. Afonso, Schuknecht and Tanzi [2006] have studied it empirically. They found that government do use more input to supply certain level of public service than necessary.

It coincides with the common sense that government is inefficient as well as government drags economy growth, e.g., Scully [1994]. Since supply and demand did not appear in their methodology, they did not provide a theoretical framework to determine simultaneously the optimal size of government and efficiency of government production as firm theory in microeconomics does.

Third, the ratio of output to input is maximized. In other words, output is maximized when input is given. If this ratio is not maximized, government is definitely inefficient. Chobanov and Mladenova [2009] reviewed literatures about the optimal size of government. In their literature list, there is no essay to discuss government efficiency based on the third concept. The objective of this paper is to analyze the third concept and then provide a clear and practical criterion to justify the optimal size of government as firm theory justifies the optimal production scale of a single firm.

It is the methodology of this paper that a microeconomic phenomenon derived from an economic agent individually is supposed to be analogous to the correspondent aggregated phenomenon. For example, Ting [2010] demonstrated that the growth of a single firm is analogous to economic growth. Besides Pareto optimum, firm theory that involves those three concepts listed above is an alternative approach to discuss efficiency in microeconomics.

Since government is a nonprofit organization, the optimal scale of a firm derived from zero profit condition is supposed to coincide with the optimal size of government.

This paper is organized as follows. I will demonstrate the theoretical coincidence in section 2 . Section 3 remarks conclusions.

\section{ANALYSIS}

Since there is no price for supply of public service, the third concept can be represented by a simple equation.

$$
M A X \frac{Q}{C(Q)}
$$

$Q$ is quantity of output and $C(Q)$ is cost function. Since cost is input in terms of money, cost and input are two ideas which are interchangeable. The solution of equation (1) is derived the first derivative.

$$
C(Q)-C^{\prime}(Q) Q=0
$$


Besides, the dual proposition of equation (1) is

$$
\sin \frac{C(Q)}{Q}
$$

Both equations (2) and (3) mean that short-run average cost is minimized, given technology and production scale. Equation (2) requires that short-run average cost should be equal to short-run marginal cost when the ratio of output to input is maximized. When profit is zero, the minimized short-run average cost is equal to market price. Thus, market price is equal to short-run marginal cost according to equation (2). It alludes that supply equals to demand in competitive market because short-run marginal cost curve is short-run supply curve under competitive market.

Notice that the demand curve of public service exists because the price of demand for public service is tax rate while there is no supply curve of public service because there is no price for supply of public service but cost. If demand for public service is greater than supply of public service (i.e., demand curve is located at right side of the minimized short-run average cost, given the production scale), government should expand production scale. Thus, the minimized short-run average cost and demand curve will intersect. In the opposite case, government should shrink production scale. To summary, equation (2) implies (1) resources are allocated as efficient as competitive market does because supply is always equal to demand by adjustment of production scale, and (2) production is efficient because output-input ratio is maximized.

Government should make tax rate and the minimized average cost even in the long run. In the short run, government is required to make short-run average cost equal to short-run marginal cost because production scale is fixed. In short, the idea of optimal size of government is identical to the concept of optimal production scale of government, which is analogous to the theory of efficiency of a single firm under zero profit condition.

\section{Conclusion}

If supply of public service is equal to demand for public service (i.e., the minimized average cost is equal to tax rate), the optimal size of government implies balance budget. Therefore, both budget deficit and budget surplus suggests inefficiency, given tax rate and public service level, because budget deficit implies oversupply and budget surplus hints undersupply. This implication supports balance budget in the long run. In addition, the optimal size of government implies minimum tax rate under balance budget because average cost is minimized and the minimized average cost is equal to tax rate.

The shortcoming of this paper is that I cannot determine that the cost function of government itself (i.e., the second concept of efficiency) is efficient or not. Since government usually has redundant resources, the cost function of government constructed by statistical data is underestimated. Therefore, the optimal size of government is overestimated. To compare the ratio of output to cost in private sector with in public sector may amend this bias instead of international comparison, which is the methodology of Afonso, Schuknecht and Tanzi [2006].

Finally, we can apply conclusions of this paper to any nonprofit organization for enhancing management efficiency.

\section{REFERENCES}

Afonso, Antonio. Schuknecht, Ludger and Tanzi, Vito. "Public Sector Efficency: Evidence for New Eu Member States and Emerging Markets," Working Paper Series, No. 581, Jan. 2006, European Central Bank.

Barro, Robert. "A Cross-Country Study of Growth, Saving and Government," NBER working paper No. 2855, 1989.

Carlstrom, Charles and Gokhale, Jagadeesh. "Government Consumption, Taxation, and Economic Activity," Federal Reserve Bank of Cleveland Economic Review, p.18-29, 1991.

Chobanov, Dimitar and Mladenova, Adriana. "What is the Optimum Size of Government," Institute for Market Economics, Bulgaria, 2009, www.ime.bg.

Heitger, B. "The Scope of Government and Its Impact on Economic Growth in OECD Countries," Kiel Institute of World Economics, Kiel Working Paper, No. 1034.

Hsieh, Edward and Lai Kon. "Government Spending and Economic Growth: the G-7 Experience," Applied Economics, p.535-42, 1994.

Karras, Georgios. "On the Optimal Government Size in Europe: Theory and Empirical Evidence," The Manchester School of Economic\&Social Studies, p.280-94, 1997.

Landau, Daniel. "Government Expenditure and Economic Growth: A Cross-Country Study," Southern Economic Journal, p.783-92, 1983.

Ram, Rati. "Government size and economic growth: a new framework and some evidence from cross-sector and time series data," American Economic Review, p.191-203, 1986.

Samuelson, Paul. "The Pure Theory of Public Expenditure," The Review of Economics and Statistics, 1954, P. 387-89.

Scully, Gerald. "What Is the Optimal Size of Government in the United States," NCPA Policy Report, No. 188, Nov. 1994.

Ting, Chao Chiung. "The optimal size of the Firm and Growth Theory," European Journal of Economics, Finance and Administrative Science, 2010, p.25-28. 